\title{
The Conceptual Approaches to the Analysis of the Labour Market and Employment
}

\author{
Tatyana V. Sarycheva ${ }^{1} \&$ Lyudmila P. Bakumenko ${ }^{1}$ \\ ${ }^{1}$ Mari State University, Yoshkar-Ola, Russia \\ Correspondence: Tatyana V. Sarycheva, Mari State University, Lenin Square 1, Yoshkar-Ola, 424000, Russia.
}

Received: February 21, 2015 Accepted: March 15, 2015 Online Published: April 29, 2015

doi:10.5539/res.v7n8p343

URL: http://dx.doi.org/10.5539/res.v7n8p343

\begin{abstract}
Economic reforms in the Russian Federation are closely connected with the problems of formation and development of the labour market. Among the new socio-economic realities, determined by the reformation processes, it is the labour market that combines the most urgent and sensitive social problems. The labour market is an essential system-forming factor of the territorial socio-economic system. Both directions and rates of macroeconomic development of a region and standard and quality of living depend on the effectiveness of the labour market. Situation at this market is the key parameter, and most indicators of socio-economic development are derived. The present article is dedicated to the development of conceptual approaches to statistical analysis of the labour market and employment at the regional level. The object of study is represented by the Volga Federal District. The subject is qualitative and quantitative laws arising in the process of the development of the labour market and the sphere of employment of the region. Information base of the study is the data presented in official collections of the Federal State Statistics Service of the Russian Federation. Within this study methodological approaches to statistical evaluation of the regions of the VFD are suggested at different levels of integration of institutional mechanism of employment system management and factors are defined, which determine the effectiveness of economic policy. These approaches are based on methods of multidimensional classification, which allowed to define territorial disproportions and to identify the groups of regions with different levels of integration activity. The main provisions, conclusions and recommendations are aimed at the improvement of the quality of statistical information on the trends in the sphere of regional employment in order to provide up-to-date effective management decisions.
\end{abstract}

Keywords: labour market, unemployment, cluster analysis, method of principal components

\section{Introduction}

State regulation of economy in Russia covers many various socio-economic systems. Quality accounting of this diversity in planning at the state level is not possible without identifying the specific features of each subject of consideration in terms of opportunities and objectives.

Due to the fact that the conditions for the formation of the labour market have significant regional differences, there is the need in state regulation of the labour market at the regional level. One of the key grounds for the development of conceptual approaches to employment analysis in regions was a provision stating that it is incorrect to set the same development goals in all regions, as well as it is incorrect to compare regions in terms of the level and opportunities for the development of the market of labour and employment. It becomes necessary to define and subsequently to substantiate the list of territories which become subjects to state support. In this regard, it becomes important to identify typological groups of regions, which determine the specifics of the corresponding territorial forecasts and plans.

\section{Methods \& Techniques}

The object of our research is the Volga Federal District, which occupies $6.1 \%$ of the territory of Russia and is one of the most diversified in terms of ethnic composition and the level of economic development. The Volga Federal District includes 14 subjects of the Russian Federation. Among them there are 6 national republics (the Republic of Bashkortostan, the Mari El Republic, the Republic of Mordovia, the Republic of Tatarstan, the Udmurt Republic, the Chuvash Republic), 7 regions (the Kirov region, the Nizhny Novgorod region, the Orenburg region, the Penza region, the Samara region, the Saratov region, the Ulyanovsk region) and the Perm krai. 
The typology of the regions of the district was carried out in two stages.

During the first stage the regions of the district were differentiated by the indicators of the labour market:

$y_{1 i}$ - the level of unemployment in $i$ region, \%;

$y_{2 i}$ - the duration of unemployment in $i$ region, months;

$y_{3 i}$ - the level of employment in $i$ region, \%;

$y_{4 i}$-the level of economic activity in $i$ region, $\%$.

Due to the fact that the increase in these four indicators has different meaning, i.e. high indicators of the level of unemployment $\left(y_{1 i}\right)$ and its duration $\left(y_{2 i}\right)$ negatively characterize the labour market and, on the other hand, high indicators of the level of employment $\left(y_{3 i}\right)$ and economic activity $\left(y_{4 i}\right)$ in the region have a positive effect on the development of market relations, indexes of the labour market indicators were taken instead of the indicators themselves, and these indexes were calculated according the following formulas:

- The following relations were used for the indicators of the level and duration of unemployment:

$$
I_{1 i}=\frac{\overline{y_{1}}}{y_{1 i}}, \quad I_{2 i}=\frac{\overline{y_{2}}}{y_{2 i}}
$$

where $\overline{y_{1}}$ - the average value of the unemployment level in the VFD;

$\overline{y_{2}}$ - the average level of the duration of unemployment in the VFD;

- For the indicators of employment and economic activity:

$I_{3 i}=\frac{y_{3 i}}{y_{3 i}}, \quad I_{4 i}=\frac{y_{4 i}}{\overline{y_{4 i}}}$

where $\overline{y_{3}}$ - the average value of the employment level in the VFD;

$\overline{y_{4}}$ - the average level of economic activity in the VFD;

The typology of the regions by labour market indicators was carried out using Ward's method, a method of cluster analysis.

At the second stage in order to analyze the typological labour markets, the set of variables was complemented by the indicators, which characterize economic policy at the regional level:

$x_{1 i}$ - share of employed at small enterprises in trade in $i$ region, \%;

$x_{2 i}$ - share of employed in trade in $i$ region, \%;

$x_{3 i}$ - share of employed in the sphere of finance and credit in $i$ region, \%;

$x_{4 i}$-share of employed at privately owned enterprises in $i$ region, \%;

$x_{5_{i}}$-share of employed at mixed ownership enterprises with the involvement of foreign capital in $i$ region, \%;

$x_{6 i}$-share of employed with higher professional education in $i$ region, $\%$;

$x_{7 i}$-share of employed with secondary vocational education in $i$ region, \%;

$x_{8 i}$-ratio of average population income per capita to the minimum of subsistence in $i$ region, units;

In order to avoid dependence on the units of measure of the indicators, at the stage of data pre-processing standardization of the data matrix $8 \times 14$ was conducted:

$$
\tilde{x}_{j}=\frac{x_{j}-\overline{x_{j}}}{\sigma_{j}}
$$

where $x_{j}$-the value of $j$ indicator for $i$ region;

$\overline{x_{j}}=\frac{1}{14} \sum_{k=1}^{14} x_{j k}$-the average value of $j$ indicator for the regions of the VFD; 


$$
\sigma_{j}=\sqrt{\frac{1}{14-1} \cdot \sum_{k=1}^{14}\left(x_{j k}-\overline{x_{j}}\right)^{2}} \text {-mean-square deviation of } j \text { indicator. }
$$

To reduce the feature space, the principal components analysis was used, which allows to move from a large set of features to a much smaller list of significant independent features through their grouping by semantic similarity, and to eliminate duplication of information by excluding uninformative or "noisy" variables. The decision on the amount of principal components was made based on the Kaiser criterion, which implies that we should use only the factors, eigen values of which are greater than 1.

The analysis of the data of Table 1 confirmed that it is sufficient to take into account three factors: $74.0 \%$ of cumulative variance is explained by the first three principal components.

Table 1. Eigen values of the principal components

\begin{tabular}{cccc}
\hline No. of the factor & Value & \% of explained variance & \% of accumulated explained variation \\
\hline 1 & 2.7 & 33.6 & 33.6 \\
2 & 2.0 & 24.8 & 58.4 \\
3 & 1.2 & 15.5 & 74.0 \\
\hline
\end{tabular}

Another problem which is solved by the method of principal components, is the formation of a composite index, values of which are determined by factor loadings. Factor loadings are the values of coefficients of correlation between each of the original features and the principal components; the closer the relationship is, the higher is the factor loading value. Additional allocation of a subset of significant coefficients is determined by the need to create a simpler structure of the principal components which is easier to interpret. Selection of the subsets of weighting factors for each principal component was carried out based on simple visual evaluation of the analytical results. We took only the weight factors, absolute values of which were greater than 0.7 . For our set of features a three-factor model was build (Table 2).

Table 2. Matrix of factor loadings

\begin{tabular}{|c|c|c|c|c|}
\hline \multirow{2}{*}{ Variables } & \multirow{2}{*}{ Names of variables } & \multicolumn{3}{|c|}{ Number of principal component } \\
\hline & & 1 & 2 & 3 \\
\hline$x_{1 i}$ & share of employed at small enterprises in trade & -0.54 & 0.30 & 0.70 \\
\hline$x_{2 i}$ & share of employed in trade & 0.02 & 0.04 & 0.79 \\
\hline$x_{3 i}$ & share of employed in the sphere of finance and credit & 0.19 & -0.89 & -0.13 \\
\hline$x_{4_{i}}$ & share of employed at privately owned enterprises & 0.41 & 0.77 & 0.05 \\
\hline$x_{5 i}$ & $\begin{array}{l}\text { share of employed at mixed ownership enterprises with the involvement } \\
\text { of foreign capital }\end{array}$ & -0.92 & -0.10 & 0.07 \\
\hline$x_{6 i}$ & share of employed with higher professional education & -0.76 & -0.21 & -0.07 \\
\hline$x_{7 i}$ & share of employed with secondary vocational education & 0.22 & 0.02 & 0.67 \\
\hline$x_{8_{i}}$ & $\begin{array}{l}\text { ratio of average population income per capita to the minimum of } \\
\text { subsistence }\end{array}$ & -0.77 & 0.49 & 0.02 \\
\hline
\end{tabular}

The data on factor loadings allowed to make conclusions about the set of original features, which reflect the principal components and the relative weight of an individual original feature in the structure of each of these components.

The first principal component included the features which characterized the share of employed at mixed ownership enterprises with the involvement of foreign capital $x_{5 i}$, the share of employed with higher professional education $x_{6 i}$ and the ratio of average population income per capita to the minimum of subsistence 
$x_{8_{i}}$. Information coefficient confirms the significance of this component $\left(K_{U 1}=0,78\right)$, which can be named as "Employment in the sphere of innovations".

In the second principal component the share of employed in the sphere of finance and credit $x_{3 i}$ and the share of employed at privately owned enterprises $x_{4 i}$ were segregated, which characterize the opportunity of employment using the provided vacancies. This determined the name of the component "Employment in the sphere of finance and credit". The value of information coefficient $\left(K_{{ }_{2}}=0,78\right)$ gives the reason to affirm that the composition of allocated features is reliable.

The third principal component included two features: the share of employed at small enterprises in trade $x_{1 i}$ and the share of employed in trade $x_{2 i}$, which determined almost $70 \%$ of the composition of the principal component. Based on the included features, the name of this component was determined as "Employment in the sphere of trade". Information coefficient $\left(K_{и з}=0,70\right)$ evidences the significance of the allocated features, which are involved in the naming of the principal component.

Typology of the regions of the Volga Federal District by indicators, characterizing the economic policy at the regional level, was carried out using k-means clustering method, which allows to form a specified number of clusters located as far as possible from each other. The principal components were used as grouping variables.

\section{Results}

As a result of the first stage of the typology (by the labour market indicators), the regions of the Volga Federal District are divided into three clusters (Figure 1).

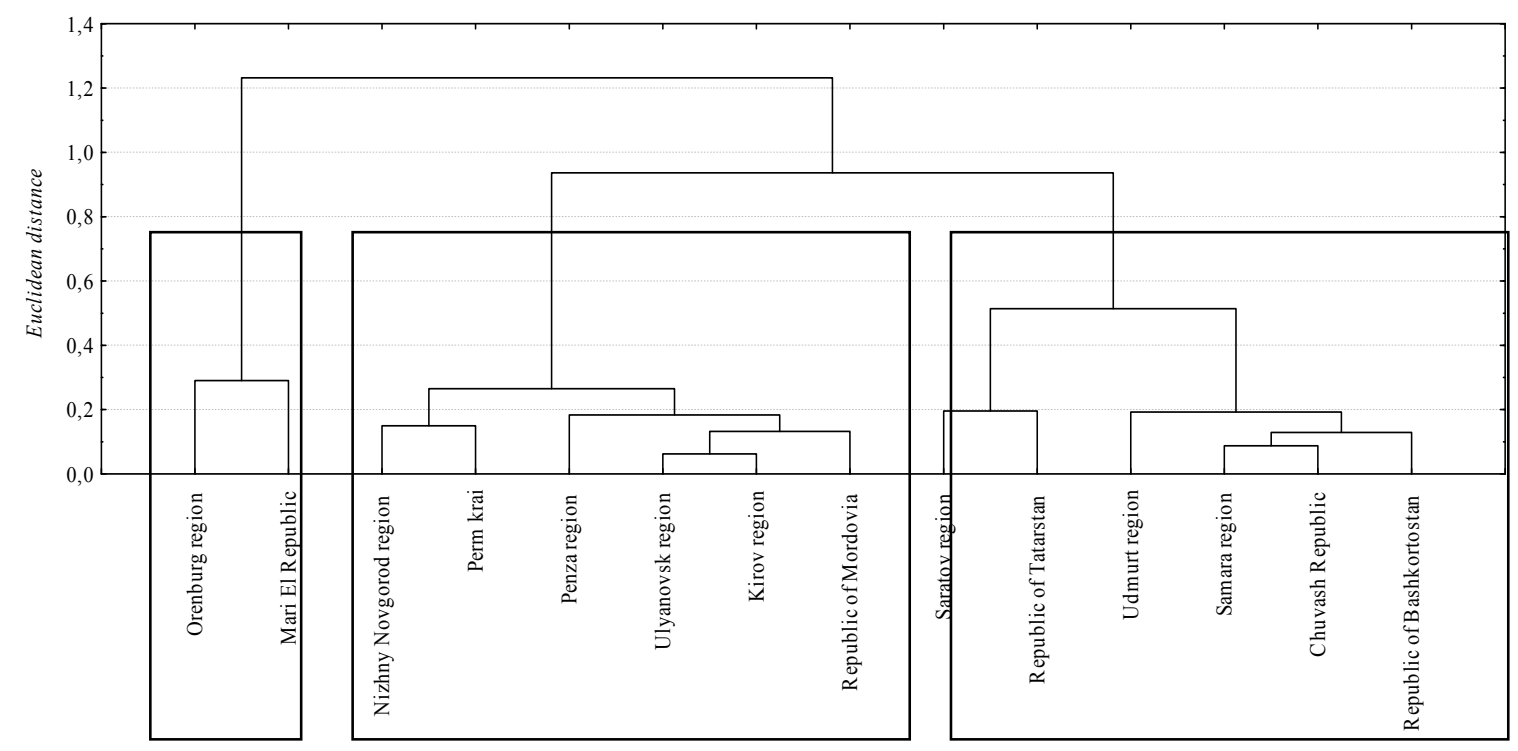

Figure 1. Dendrogram of multidimensional differentiations of the regions of the VFD by the labour market indicators

The status of the cluster is important for regional authorities, as it develops and strengthens the economy, stimulates economic growth and accelerates the solution of social problems by creating the conditions for successful development of the less advanced areas. The subjects included to the same group, on the one hand had close values of the labour market indicators (Table 3), and on the other hand, had common trends of socio-economic development. 
Table 3. Average labour market indicators

\begin{tabular}{ccccc}
\hline $\begin{array}{c}\text { Number of } \\
\text { cluster }\end{array}$ & $\begin{array}{c}\text { Unemployment } \\
\text { level, \% }\end{array}$ & $\begin{array}{c}\text { Duration of unemployment, } \\
\text { months }\end{array}$ & $\begin{array}{c}\text { Employment } \\
\text { level, \% }\end{array}$ & $\begin{array}{c}\text { Level of economic } \\
\text { activity, \% }\end{array}$ \\
\hline 1 & 5.2 & 7.3 & 89.1 & 68.8 \\
2 & 5.7 & 7.8 & 91.7 & 68.4 \\
3 & 6.0 & 8.0 & 94.4 & 68.1 \\
\hline
\end{tabular}

The first cluster, which included the Saratov and Samara regions, the Udmurt and Chuvash Republics and the Republics of Tatarstan and Bashkortostan, had in 2012 the most favourable conditions, prevailing at the regional labour market. Rather high level of economic activity $(68.8 \%)$ was determined by the low level of unemployment (5.2\%) and short periods of job search (7.3 months). This group of regions can be called "Regions - engines of growth" as they met the following conditions. Firstly, in these regions the majority of all enterprises of the Volga Federal District is located, $56 \%$ of which are commercial and are aimed at making profit. Turnover of enterprises of the subjects in this cluster is $59.6 \%$ of the total cash turnover in the district. Secondly, these regions make a significant contribution to the GRP augmentation of the Volga Federal District, which is primarily due to the fact that among the leaders there are regions, in which oil and gas extraction is carried out (the Republic of Bashkortostan, the Udmurt Republic). This has a profound impact on the specifics of business in these regions. Subjects of this group account for 53\% of foreign investments. Analysis of the data shown in the Figure 2.6 clearly proves that six regions-leaders produce almost $57 \%$ of gross regional product. This indicates that, unfortunately, institutional mechanisms in other regions of our country cannot attract foreign investments so effectively (Figure 2).

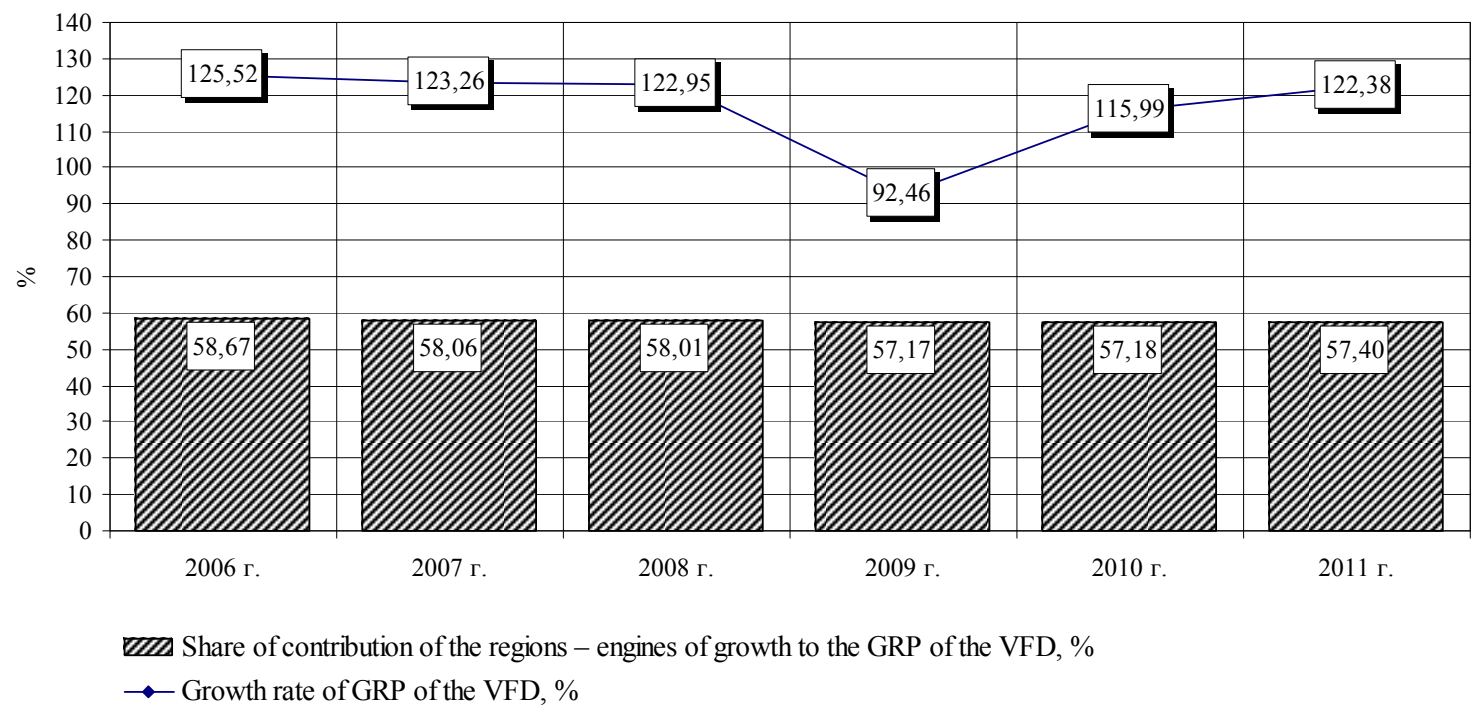

Figure 2. GRP dynamics in the VFD, 2006-2011

Thirdly, the regions of this group have high scientific and technical potential. These regions comprise enormous intellectual resources and leading universities and, simultaneously, export resources and appropriate financial resources. In 2012, 56.8\% of enterprises of the district, which perform research and development, were located in the regions of this group. It is this group where $62.6 \%$ of all patents (in the district) for inventions and $62.0 \%$ of patents for useful models were obtained (useful models allow to increase the productivity of workers significantly). In this case, the costs for research and development accounted for only $36.8 \%$ of the internal costs for these activities of the whole Volga Federal District. On average, $41.9 \%$ of enterprises in this cluster have their websites, while for the whole district this indicator is $38.7 \%$. Thus, on a short-term horizon the regions of the first cluster can become the development centres for neighbouring regions, and the prospects of their 
development are the most foreseeable. Finance and economic centres will keep their leadership regardless of the development trends of the Volga Federal District as a whole; they will remain the centres of decision-making and implementation of innovations and post-industrial regions of the district. Export-oriented regions, which are rich in raw materials, will remain critically important for both the Volga Federal District and the Russian economy as a whole due to the uniqueness of their resources.

The second cluster included "Supporting regions": the Nizhny Novgorod, Penza, Ulyanovsk and Kirov regions as well as the Perm krai and the Republic of Mordovia, where the situation at the labour market in 2012 was quite favourable. Thus, the average employment level was $91.7 \%$, which was primarily due to the average share of economically active population (only 68.4\%). The unemployment was also at an average level (5.7 on the cluster average), while the time spent on job search was rather long-7.8 months. Economic activity of the population primarily depends on the age composition and population income. In 2012, the regions of the second cluster were characterized by the highest proportion of the number of pensioners. Thus, in 2012 there were 305.9 pensioners per 1000 people. On average in the district, this indicator does not exceed 287.8, and in the first cluster the value is 277.6. Despite the fact that the load of unemployed population per one worker is rather high, the subjects of this cluster had high levels of real cash income (112.2\% on average) and the real gross payroll (127.5). Social transfers made positive contribution to the growth of incomes of the population. In 2012, the given regions were characterized by traditional industrial productions, currently experiencing a structural crisis, namely the lack of market positioning. Only $36.5 \%$ of enterprises and organizations have their own websites. The analysis of the share of organizations, which used information and communication technologies, in the total number of organizations showed, that in terms of all the main characteristics, such as using PCs and other computers, local and global information systems, the regions of the second cluster lag far behind the district indicators (Figure 3).

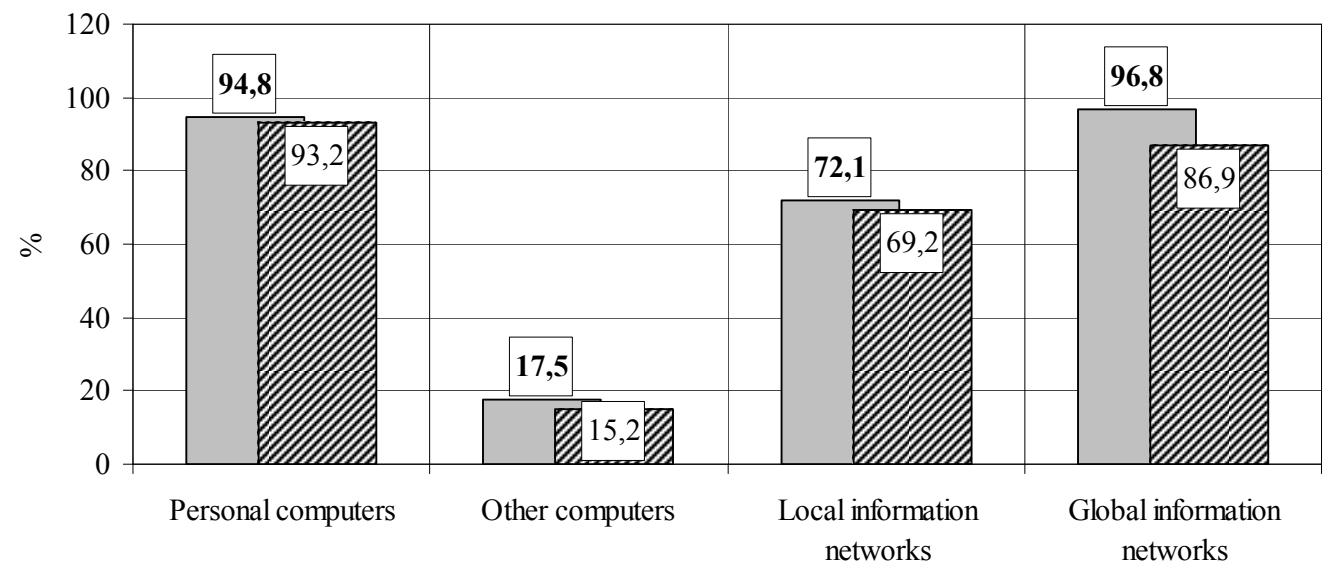

$\square$ VFD $\square$ Supporting regions

Figure 3. Share of the organizations, which used information and communication technologies, in the total number of observed organizations, $\%$

Supporting regions may represent cumulative portrait of the Volga Federal District with all its national specifics and all difficulties. In the future, it is primarily necessary for these regions to improve the competitiveness of the leading economic activities. At present, the regions of the second cluster act like resource donors for the capital agglomerations, oil-producing regions and other territories with higher level of development. Working population moves to bigger wages and wider variety of jobs, and capital companies jostle local competitors at regional consumer markets, in financial sector and in business services. The supporting regions should focus on the implementation of production functions as well as on the attraction of external investors. Creating the conditions for localization of not only the new productions, but also the firms of tertiary sector (finance, business services) in these regions also can become an important component of the policy of regional development.

The third cluster, represented by the Orenburg region and the Mari El Republic, was characterized by the highest unemployment level, which was $6.0 \%$ on the cluster average, with an average of the Volga Federal District of $5.5 \%$. But despite the fact that in 2012 in these regions the employment level, calculated for economically active 
population, was the highest (94.4\%), economic activity in the analyzed period was the lowest $(68.1 \%)$. In this regard, the Mari El Republic and the Orenburg region were classified as "Depressive regions". In 2012, these regions were characterized by significant economic downturn in the main economic activities. In financial terms, the regions of the third cluster are subsidized, and the basis of the formation of local budget is insufficient. The territory of depressive regions had a low standard of living, outdated technological base, insufficient market positioning and shortage of staff. Thus, for example, in 2012, in the Mari El Republic depreciation of fixed assets had the maximum value in the district $(60.6 \%)$, which put it on the $80^{\text {th }}$ place among the regions of the Russian Federation. The Mari El Republic was also at the $80^{\text {th }}$ place among the Russian regions and at the last place among the regions of the Volga Federal District in terms of the per capita income, which was 12538 rubles in the analyzed period with the average of the district of 19597 rubles. We should point out that, in contrast to the Mari El Republic, the Orenburg region had a much better position. In 2012, depreciation of fixed assets was 56.9\% $\left(9^{\text {th }}\right.$ place among the VFD regions). As for the per capita income, the giver subject took the $5^{\text {th }}$ place in the district (16539 rubles). Critical situation at the labour market in this region is connected with the liquidation of major industrial enterprises and the lack of jobs. More than 300 thousand people ( $30 \%$ of economically active population) have informal employment (small business, crafts, part-time job in construction, trade and service). The largest share of informal employment is in agriculture (75\%), trade and consumer services $(61 \%)$, food processing (40\%), construction (36\%), transport and communication (34\%). The transition of depressive regions to the path of sustainable economic development can be provided through diversification, conversion and modernization of production, stimulation of the development of small business, improvement of local investment sphere, search for new sales markets, etc. Also, these regions should obtain targeted state support.

At the second stage of typology, at which the subjects of the Volga Federal District were studied in terms of indicators of the efficiency of economic policy, regions of the district also formed three unequal in size and qualitatively different groups, which is clearly shown by a comparison of the average values of the principal components (Figure 4)

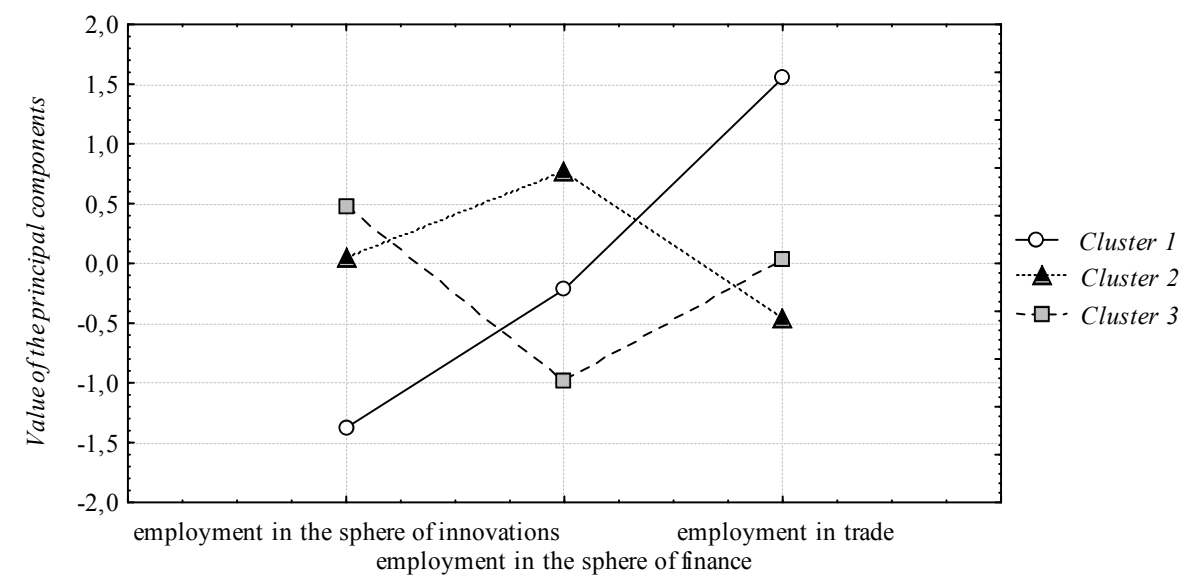

Figure 4. Average values of the principal components by clusters

The first cluster included "Developed regions": the Samara and Nizhny Novgorod regions, which belong to service regions. In 2012, these subjects were distinguished by the great development of the "new sector". They were characterized by high level of employed in trade, both at all enterprises and organizations and at small enterprises. These indicators exceed the corresponding district parameters approximately by $17.6 \%$. Along with this, in this cluster the regions are presented with a large proportion of workers, who have higher and secondary education. These indicators were $3100 \%$ and $28.4 \%$ on cluster average; these values were only $27.2 \%$ and $26.1 \%$ on average for the Volga Federal District. This group corresponded to the highest level of income per capita, which exceeded the living standard by 4.1 times (Table 4). 
Table 4. Average values of the indicators of the "new sector" development by clusters

\begin{tabular}{|c|c|c|c|c|c|c|c|c|c|}
\hline $\begin{array}{l}\text { No. of } \\
\text { cluster }\end{array}$ & Composition of the cluster & $x_{1 i}$ & $x_{2 i}$ & $x_{3 i}$ & $x_{4 i}$ & $x_{5_{i}}$ & $x_{6 i}$ & $x_{7_{i}}$ & $x_{8 i}$ \\
\hline 1 & Nizhny Novgorod region; Samara region & 6.4 & 19.9 & 6.6 & 61.4 & 6.7 & 31.0 & 28.4 & 4.1 \\
\hline 3 & $\begin{array}{l}\text { Republic of Bashkortostan; Republic of } \\
\text { Tatarstan; Udmurt Republic; Chuvash } \\
\text { Republic; Perm krai; Orenburg region; Penza } \\
\text { region }\end{array}$ & 4.5 & 16.8 & 6.2 & 64.2 & 3.1 & 25.9 & 25.4 & 3.8 \\
\hline 2 & $\begin{array}{l}\text { Mari El Republic; Republic of Mordovia; } \\
\text { Kirov region; Saratov region; Ulyanovsk } \\
\text { region }\end{array}$ & 3.6 & 16.8 & 8.0 & 61.1 & 2.6 & 26.1 & 26.8 & 2.9 \\
\hline & Average for the VFD & 4.6 & 17.0 & 6.6 & 53.7 & 4.0 & 27.2 & 26.1 & \\
\hline
\end{tabular}

In the analyzed period, subjects of the first cluster were characterized by developed market institutes and better quality of regional management (public administration, budgetary financing), stable image of reformation and regional policy openness). This resulted in high indicators of the volume of investments in fixed capital and per capita, as well as high indicators of shipped production, profits of enterprises and tax and non-tax revenues, collected in consolidated budget. This, in 2012, the developed regions accounted for almost one-fifth of all investments in fixed assets of the total volume of investments in the Volga Federal District (70961 rubles per capita), while the district value was 66483 rubles. Profit of the organizations of the Nizhny Novgorod and Samara regions was $25.2 \%$ of the total profit of the district, and the revenues of consolidated budget was only $21.78 \%$ of the total budget of the Volga region; the largest share of these revenues was represented by tax revenues (Table 5).

Table 5. Indicators of economic activity results in the developed regions, 2012

\begin{tabular}{|c|c|c|c|}
\hline Indicator & $\begin{array}{l}\text { Developed } \\
\text { regions }\end{array}$ & VFD & $\begin{array}{l}\text { Share of developed regions in the total } \\
\text { volume of the indicator in the VFD }\end{array}$ \\
\hline Investment in fixed capital, mln rub. & 462341 & 1980652 & 23.34 \\
\hline $\begin{array}{l}\text { Investment in fixed capital per } \\
\text { capita, thousand rub. }\end{array}$ & 70961 & 66483 & \\
\hline \multicolumn{4}{|l|}{$\begin{array}{l}\text { Volume of shipped production, mln. } \\
\text { rub. }\end{array}$} \\
\hline Mineral extraction & 173578 & 1355243 & 12.81 \\
\hline Processing industries & 1655101 & 5687482 & 29.10 \\
\hline $\begin{array}{l}\text { Production of electricity, gas and } \\
\text { water }\end{array}$ & 179280 & 766523 & 23.39 \\
\hline Profit of enterprises, mln. rub. & 263756 & 1046526 & 25.20 \\
\hline $\begin{array}{l}\text { Consolidated budget revenues, } \mathrm{mln} \text {. } \\
\text { rub. }\end{array}$ & 198260.8 & 910340 & 21.78 \\
\hline Tax revenues, rub. & 125252.4 & 471665 & 26.56 \\
\hline
\end{tabular}

In these cluster the problems of the other regions are less urgent as the transport infrastructure is more developed. The subjects of the first cluster account for $36.8 \%$ of passengers carried by public railway system and $28.1 \%$ of passengers carried by public buses. These regions are distinguished by high density of public railways and public roads with hard surface (Figure 5). At the same time, there are the benefits of transit location. On the territory of the Samara and Nizhny Novgorod regions there are the main federal public roads which connect the Central and North-West Federal Districts with the Ural, Siberian and Far Eastern Federal Districts and the Republic of Kazakhstan. 


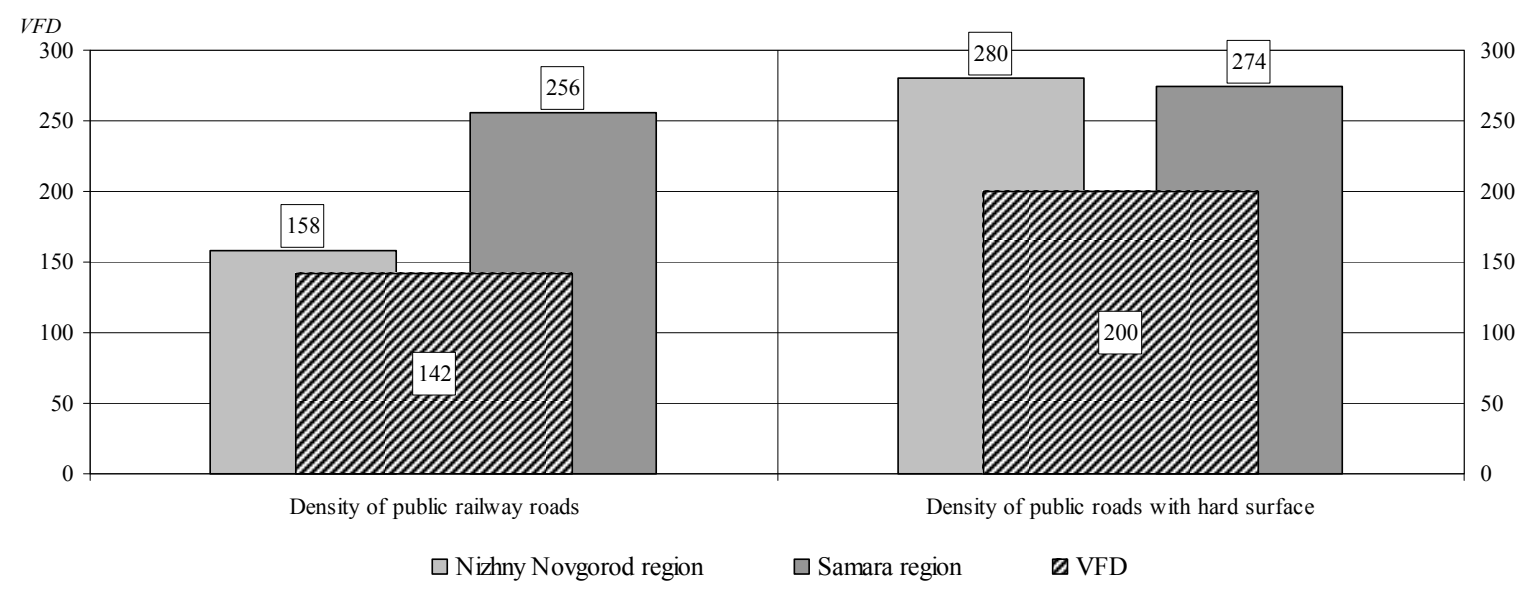

Figure 5. Density of railway roads and roads with hard surface

The Samara and Nizhny Novgorod regions are distinguished by high level of urbanization $(80.3 \%$ and $79.1 \%$ of urban population respectively) and good infrastructure. Powerful agglomeration promotes concentration of employment places and sales markets, expanding profitable economic activities and diffusion of innovations beyond the area. Around the world, modernization of values, motivations and behaviour, including consumer behaviour, is spreading not across regions, but across the hierarchical systems of cities, from the largest to the smallest. In Russia, the diffusion of innovations "stuck" at the level of regional capitals and major cities with export economics. Service sector is developing faster and modernization of lifestyle is accelerating only in the regions, which contain major city agglomerations. Besides, only major agglomerations are able to partially counterbalance Moscow, which "takes" from the regions both financial and human resources.

The second cluster, the largest, included seven specialized regions: three agro-industrial regions (the Republic of Bashkortostan, the Orenburg and Penza regions); two industrial regions (the Republic of Tatarstan, the Udmurt Republic and the Perm krai) and one mixed region (the Chuvash republic). This cluster was named "Inertial regions". The values of indicators in this cluster are the closest to the average district values. Only the indicator, which characterizes the share of employed at private enterprises, exceeds the average district value by almost $20 \%$, which is primarily connected with the share of private enterprises in the total number of enterprises and organizations of the regions of the second cluster (Figure 6).

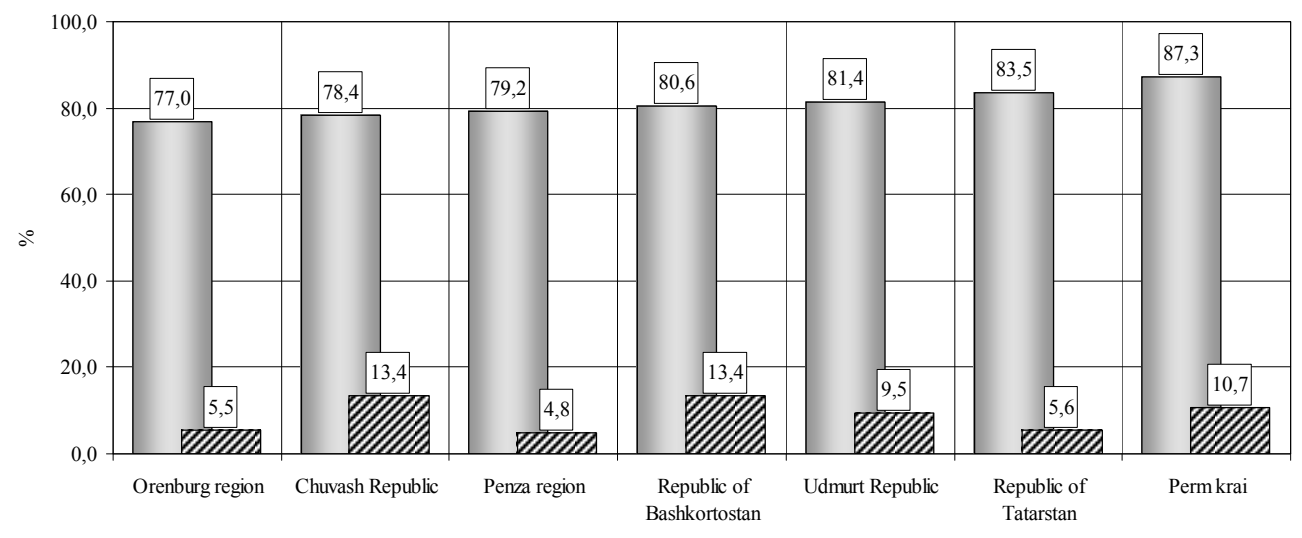

$\square$ Share of private enterprises in the total number of enterprises and organizations of the region, $\%$ च Share of small enterprises in the total number of small enterprises in the VFD, $\%$

Figure 6. Distribution of enterprises in the second cluster by forms of property and types, $\%$

Subjects of the second cluster are distinguished by well developed private sector. Total share of privately owned enterprises in the inertial regions is $82 \%$ of the total amount of enterprises and organizations in these regions. It 
is necessary to underline that it is the second cluster where most small enterprises of the Volga Federal District are located $(55.9 \%)$. This cluster is also characterized by the lowest indicators of education of employed population. The number of staff members of enterprises and organizations in this cluster, who have higher and secondary vocational education, is slightly above $50 \%$, which is the consequence of underdevelopment of services and may soon lead to deceleration of industrial modernization in these regions. Since specialists with higher education will move to capital regions in pursuit of higher wages, and specialists with secondary and primary vocational education will stay in these regions as the territories with developed processing and mining industry (Fig. 7).

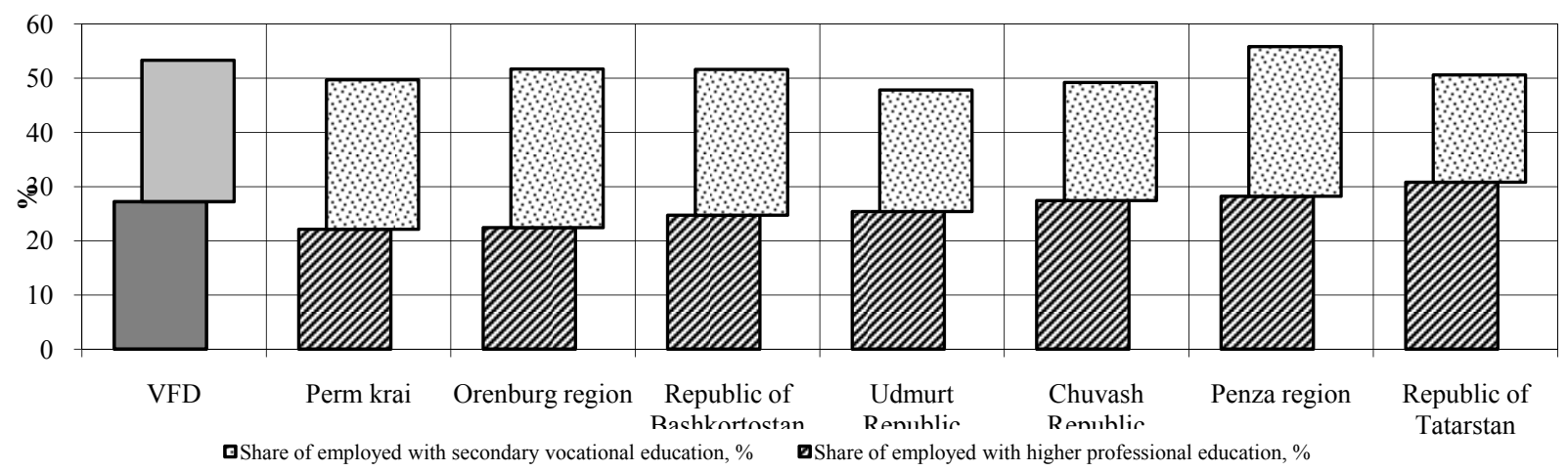

Figure 7. Distribution of employed in the second cluster by education level, $\%$

The third cluster "Lagging regions" is represented by five subjects, three of which are service (the Mari El Republic, the Kirov and Saratov regions); one subject is agroindustrial (the Republic of Mordovia) and one region is mixed (the Ulyanovsk region). In 2012, the subjects of this group were characterized by high share of employment in the sphere of finance and credit, development of which is determined by low living standard of these regions (people "live on credit"). This is primarily evidenced by the ratio of average population income per capita to the minimum of subsistence, which is only 2.9 for this group. Wages remain the main source of income of population, and business income accounts for only $7.5 \%$ in the Kirov region and $9.2 \%$ in the Mari El Republic (Table 6).

Table 6. Distribution of the main sources of income in the regions of the third cluster

\begin{tabular}{|c|c|c|c|c|c|c|}
\hline Indicators & VFD & $\begin{array}{c}\text { Mari El } \\
\text { Republic }\end{array}$ & $\begin{array}{l}\text { Republic of } \\
\text { Mordovia }\end{array}$ & $\begin{array}{l}\text { Kirov } \\
\text { region }\end{array}$ & $\begin{array}{l}\text { Saratov } \\
\text { region }\end{array}$ & $\begin{array}{l}\text { Ulyanovsk } \\
\text { region }\end{array}$ \\
\hline Income from bussiness activity & 9.9 & 9.2 & 9.0 & 7.5 & 8.6 & 8.9 \\
\hline Wages & 36.4 & 42.6 & 40.5 & 38.8 & 40.9 & 36 \\
\hline Social payments & 19.7 & 28.9 & 29.0 & 25.8 & 26.7 & 25.1 \\
\hline Income from property & 3 & 3.2 & 2.6 & 2.4 & 3.2 & 2.3 \\
\hline $\begin{array}{l}\text { Other income (including "hidden" } \\
\text { income, income from currency } \\
\text { sale, money orders, etc.) }\end{array}$ & 31 & 16.1 & 18.9 & 25.5 & 20.6 & 27.7 \\
\hline
\end{tabular}

The main obstacles to the development of the "new sector" in the subjects of the third cluster are primarily connected with the following problems: restrictions in transport and energy infrastructure; predominance of asset intensive, material- and energy intensive production capacities; low labour productivity in economic sectors, which make the greatest contribution to the GDP; high level of depreciation and obsolete fixed assets and, consequently, technological backwardness and low competitiveness of production; lack of effective interaction between the regions; low interaction between production and research; insufficiently effective social infrastructure.

Grouping using cluster analysis, based on the labour market indicators, was compared to the classification, 
carried out on the basis of grouping of shares of employed in private sector, at small enterprises, in infrastructure sectors, etc (Table 7).

Table 7. Evaluation of the impact of economic policy on the indicators of the labour market of the regions of the VFD

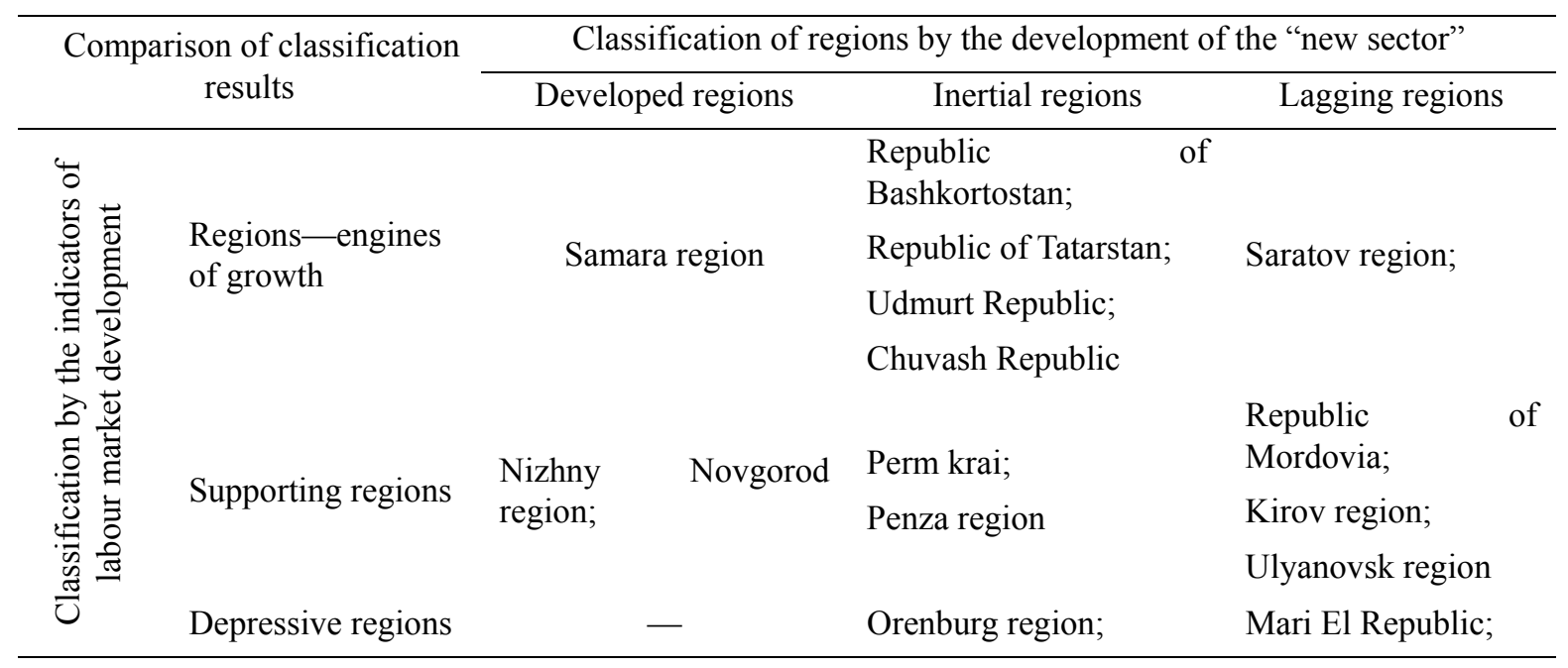

The obtained results show that the regions with higher share of the new sector in the structure of employment formed the group with the better position at the labour market, while the regions with comparatively low share of the new sector created a group with worse position at the labour market. This applies to the regions of all segments of the labour market: agroindustrial, mixed and service sectors.

\section{Discussion}

Study of the labour market and impact of various factors on it is reflected in works of many Russian and foreign scientists: B. I. Bashkatov, I. E. Ilyukhina, M. V. Karmanov, F.N. Kibanov, O. V. Kuchmaeva, N. P. Maslova, S. Y. Nikitina, R. P. Rudakova, V. M. Simchera, N. M. Khorchenko, S. Y. Shcherbov and others. During the development of methodological issues of the conducted statistical study the following works of Russian scientists were of great importance: T. N. Agapova, O. E. Bashina, A. M. Dubrov, T. A. Dubrova, I. I. Eliseeva, M. R. Efimova, V. G. Minashkin, V. S. Mkhitaryan, B. T. Ryabushkin, N. A. Sadovnikova, R. A. Shmoilova and others. The promlems of the formation of the regional labour markets and the analysis of the indicators of thei development are studied in the works of A. G. Granberg, S. D. Ilyenkova, I. A Polyakova, V. A. Sivelkina, N. V. Savchuk and others.

At the same time, many issues connected with the improvement of analysis and forecasting of the development of the regional labour market, especially during economic crysis and recovery, are not sufficiently studied, which makes it necessary to develop conceptual approaches to the analysis of regional labour markets. Complexity and diversity of problems of the regional labour markets, which are not yet worked out both practically and theoretically, make this study urgent.

\section{Conclusions}

Modern economy of the Volga Federal District is characterized by regionally segmented labour market with ineffective structure of employment, which includes non-competitive regional clusters. This is due to the fact that, firstly, the regions have different initial conditions for the reformation of the labour markets, and, secondly, they carry out different economic policies, which include such measures as creating the conditions for the development of private property, small and medium business, support of the sector of credit and finance, trade, local infrastructure (road and transport, telecommunication, etc.) and investments to human resources.

All regions spend significant amount of funds on institutional development, but privileges at the labour market belong to the regions with high level of institutional development and effective structure of employment. The structure of employment by the types of economic activities is formed in a long-term period and is determined by state strategy of production location within the country. Institutional structure of employment largely depends on economic policy of the region, support of small and medium business, increase in the number of private 
enterprises and mixed property with foreign participation, development of the regional infrastructure and investments to human resources.

In case of regional economic policy, which is aimed at improving the effectiveness of the institutional structure of employment, the risk of unemployment decreases. The regions, which have low share of small and medium business and private sector, insufficient level of infrastructure and education, are distinguished by high risk of unemployment.

Thus, unfavorable initial conditions for reformation of the labour market and ineffective structure of employment to a certain extent can be compensated by regional economic policy, aimed at the development of non-state sector in the regional economy, small and medium business, regional infrastructure and the increase in investments to human resources.

Currently one of the most negative trends is intensified differentiation of the levels of development of the market of labour and employment, which leads to the difference in social and economic development of the regions and in progressive lag of significant group of regions. It is connected, firstly, with the mechanism of market competition, which divides regions by its competitive advantages and disadvantages; there is also unequal adaptation to the market of the regions with different economic structure and different mentality of the population and authorities. Secondly, the regulatory role of the state has significantly weakened, which resulted in reduction of state investments in regional development and cancellation of most regional economic and social compensations. Thirdly, there is actual inequality of different subjects of the Volga Federal District in terms of economic relations with the central part of the country.

Classification of territories by the level of the developments of the markets of labour and employment, allocation of groups of regions with similar problems allowed to determine the objectives of development, which should become the main tasks for these territories. It is an essential step to formulate and carry out adequate regional policy. Moreover, it allows to set not only short-term goals for the group of territories, but also to determine long-term opportunities for the regional development.

At the same time, well-developed classification of the regions created an adequate base for the analysis of the development of groups, which helps to evaluate whether the suggested regional measures are conjecture or deliberate long-term strategy, and allows to move the discussion of the problems of regional policy at the new quality level.

\section{Acknowledgment}

This article was prepared under a grant of the Russian Humanitarian Science Foundation (project "Demoekonomichesky potential of the region: macrosystemic approach" \# 15-02-00567).

\section{References}

An introduction to data cleaning with R. (2013). Statistics Netherlands. Retrieved from http://cran.r-project.org/doc/contrib/de_Jonge+van_der_Loo-Introduction_to_data_cleaning_with_R.pdf

Brand, M. (2002). Incremental singular value decomposition of uncertain data with missing values. ECCV, 707-720. http://dx.doi.org/10.1007/3-540-47969-4_47

Brand, M. (2006). Fast low-rank modifications of the thin singular value decomposition. Linear Algebra and its Applications, 415(1), 20-30. http://dx.doi.org/10.1016/j.laa.2005.07.021

Costello, A. B., \& Osborne, J. W. (2005). Best Practices in Exploratory Factor Analysis: Four Recommendations for Getting the Most From Your Analysis. Practical Assessment Research \& Evaluation, 10(7). Retrieved from http://pareonline.net/pdf/v10n7.pdf

Graham, R. L. (1972). An efficient algorithm for determing the convex hull of a finite point set. Information Processing Letters, 1(4), 132-133. http://dx.doi.org/10.1016/0020-0190(72)90045-2

Mulaik, S. A. (1990). Blurring the Distinctions between Component Analysis and Common Factor-Analysis. Multivariate Behavioral Research, 25(1), 53-59. http://dx.doi.org/10.1207/s15327906mbr2501_6

Murtagh, F., \& Legendre, P. (2011). Ward's Hierarchical Clustering Method: Clustering Criterion and Agglomerative Algorithm. Retrieved from http://arxiv.org/pdf/1111.6285.pdf

Velicer, W. F., \& Fava, J. L. (1998). Effects of variable and subject sampling on factor pattern recovery. Psychological Methods, 3(2), 231-251. http://dx.doi.org/10.1037/1082-989X.3.2.231

Ward, J. H. (1963). Hierarchical grouping to optimize an objective function. Journal of the American Statistical Association, 58, 236-244. http://dx.doi.org/10.1080/01621459.1963.10500845 
Pham, D. T., Dimov, S. S., \& Nguyen, C. D. (2004). Selection of K in K-means clustering. Mechanical Engineering Science, 219(Part C), 103-119.

\section{Copyrights}

Copyright for this article is retained by the author(s), with first publication rights granted to the journal.

This is an open-access article distributed under the terms and conditions of the Creative Commons Attribution license (http://creativecommons.org/licenses/by/3.0/). 